\title{
APPLICATION OF HEALTH PROTOCOLS FOR THE RESUMPTION OF ACTIVITIES IN ARCHITECTURE AND ENGINEERING PROJECTS WITH THE AID OF DIGITAL TECHNOLOGY FOR POST- PANDEMIC
}

Maria Paula Dunela Ingrid Joyce Almeida de Jesus $^{b}$

\author{
${ }^{a}$ Architect and teacher, Federal University of Bahia, Brazil. \\ ${ }^{b}$ Architect, Frei Paulo, Sergipe, Brazil.
}

\begin{abstract}
The process of economic reopening in the countries affected by the new coronavirus is being widely discussed and experienced in an unconsolidated way across the globe. This work has models / solutions that can be adapted to different areas, allowing a safe return to the work environment. The solutions proposed in this work aim to provide a safe transition in the reopening of the gym and beauty salon environments, applying the guidelines and protocols of the competent bodies and facilitating the understanding of the public. Based on the results presented, it is possible to affirm that the redesign of the environment contributes to the safety of the people who frequent these spaces, since there was their optimization.
\end{abstract}

Keywords: novo coronavirus; pandemic; architecture and engineering; redesign of the environments.

\section{APLICAÇÃO DOS PROTOCOLOS DE SAÚDE PARA A RETOMADA DAS ATIVIDADES NOS PROJETOS DE ARQUITETURA E ENGENHARIA COM O AUXÍLIO DA TECNOLOGIA DIGITAL PARA O PÓS- PANDEMIA}

Resumo: O processo de reabertura econômica dos países afetados pelo novo coronavírus está sendo amplamente discutido e experienciado de forma não consolidada em todo o globo. Este trabalho conta com modelos/soluções, elaborados com o auxílio da tecnologia digital, que podem ser adaptados para as diferentes áreas, permitindo uma retomada segura ao ambiente de trabalho. As soluções propostas nesse trabalho têm por objetivo proporcionar uma transição segura na reabertura dos ambientes academia e salão de beleza, aplicando as diretrizes e os protocolos dos órgãos competentes e facilitando o entendimento do público em geral. Com base nos resultados apresentados é possível afirmar que a repaginação do ambiente colabora com a segurança das pessoas que frequentam esses espaços, visto que houve a otimização deles.

Palavras-chave: covid-19; pandemia; arquitetura e engenharia; repaginação dos ambientes. 


\section{INTRODUCTION}

The pandemic of the new coronavirus has been causing numerous changes in all spheres of society, forcing everyone to live a new reality. These transformations pass through the fields of politics, economics, culture, business, social relations and the relationship of man with the space in which he lives. This moment leads us to reflect on aspects of our lives and compels us to seek solutions and establish new goals in the post-pandemic world. Considering this, the process of economic reopening in countries affected by the virus is being widely discussed and experienced in an unconsolidated way across the globe.

Returning to work requires thorough planning in the organization of physical spaces to prevent and maintain the health of employees. Therefore, workspaces will undergo changes at all levels: physical, hygienic and in personal relationships.

Given the circumstances, this research was developed, developed following the guidelines of the World Health Organization (WHO). The research has a series of useful information and recommendations for the resumption of post-pandemic activities of the new COVID-19.

To help solve these problems, this research was carried out based on the guidelines developed by $\mathrm{WHO}$, by the health agencies, as well as some models adopted in countries where the reopening of trade has already been applied, such as the case of Italy and China.

This work has models / solutions developed with the aid of digital technology that allows a better visualization and understanding of protocols in the environments of the gym and the beauty salon that can be adapted to the various commercial areas, allowing a safe resumption to the work environment, as well as the well-being of workers.

\section{METHODOLOGY}

The gym and the beauty salon are places of socialization, according to the researchers [1] and [2], respectively, and for this reason they are considered high-risk environments for resuming activities.

This work is based on this premise and seeks to readjust the environments so that the return to activities can occur safely in them.

Thus, this research is characterized by being a work of research and action. Where the guidelines of WHO and health agencies will be applied to see the space for the reopening of post-pandemic activities.

The research was divided into two stages, the first consisted of a search for the protocols applied to these sectors and also a search for the European and Asian countries that have already opened these environments. The second stage consisted of the application of protocols in architectural plans elaborated with the help of the AutoCAD ${ }^{\circledR}$ and $\operatorname{Revit}^{\circledR}$ programs, which allowed to externalize and explain the concepts applied, facilitating understanding and promoting an immediate understanding. The research shows what the layout was like in the pre-pandemic and how it will be in the post-pandemic in Brazil. 
The work was developed applying the main guidelines of the World Health Organization [3], the protocols of the civil construction agencies - Council of Architecture and Urbanism of the Federal District and Paraiba [4,5], of the reopening plans of the states of São Paulo and Sergipe [6,7], and the plan to resume the activities of the Federation of Industries of the State of São Paulo [8], according to the need for each specific case (Table 01).

Table 01: Main guidelines applied to research

\begin{tabular}{l}
\hline Modification of the layout of each environment respecting social distance; \\
\hline Floor demarcation for queue and flow management; \\
\hline Placement of a sign indicating the maximum number of people, to ensure social \\
distance in the environments; \\
\hline $\begin{array}{l}\text { Application of more sanitation stations in the accesses of each environment, and the } \\
\text { provision of gel alcohol for hands in the work environments; }\end{array}$ \\
\hline Installation of hand washing stations outside the building, or gel alcohol dispenser; \\
\hline $\begin{array}{l}\text { Maintain well ventilated environments, and clean the air conditioners with high } \\
\text { frequency; }\end{array}$ \\
\hline $\begin{array}{l}\text { Use physical barriers or specific PPE for protection between people, in the form of } \\
\text { transparent partitions or face shields, whenever the minimum distance between } \\
\text { people cannot be maintained. }\end{array}$
\end{tabular}

Source: [3] ;[4]; [5] ; [7];[8].

Based on the general guidelines of the bodies, the guidelines were extracted in a way that relates to the redesign of the environments. To be able to apply the models, a standard symbology was created (Table 01):

Table 01: Symbology for the application of the repagination of layouts

\begin{tabular}{c|l}
\hline & \multicolumn{1}{c}{ Reference } \\
\hline & Social distance of $1.5 \mathrm{~m}$ radius \\
\hline & Space demarcation \\
\hline & Sanitary mat \\
\hline & Physical protection barrier \\
\hline & Single circulation direction \\
\hline
\end{tabular}

Source: The authors. 


\subsection{Gym Model}

Regular physical activity is a practice recommended by the World Health Organization (WHO) and an important element in disease prevention, being essential for modern man to have a superior quality of life.

According to [9], gyms are considered the main places of physical activity in the great Brazilian urban centers, and great allies for maintaining people's physical and mental health.

In addition, the Brazilian gym market is the second in number of establishments, second only to the United States of America, according to the International Health, Racquet \& Sportsclub Association [10].

Therefore, this study seeks to readjust these environments for a safe return of activities in the post-pandemic reopening. The gym model adopted (Figure 01) has a total area of $427.05 \mathrm{~m}^{2}$ and has a reception of $21.25 \mathrm{~m}^{2}, 01$ training hall of $300.20 \mathrm{~m}^{2}$, 02 changing rooms of $41.28 \mathrm{~m}^{2}$ each and 02 meeting rooms of $1152 \mathrm{~m}^{2}$ each.

Figure 01: Pre-pandemic gym layout

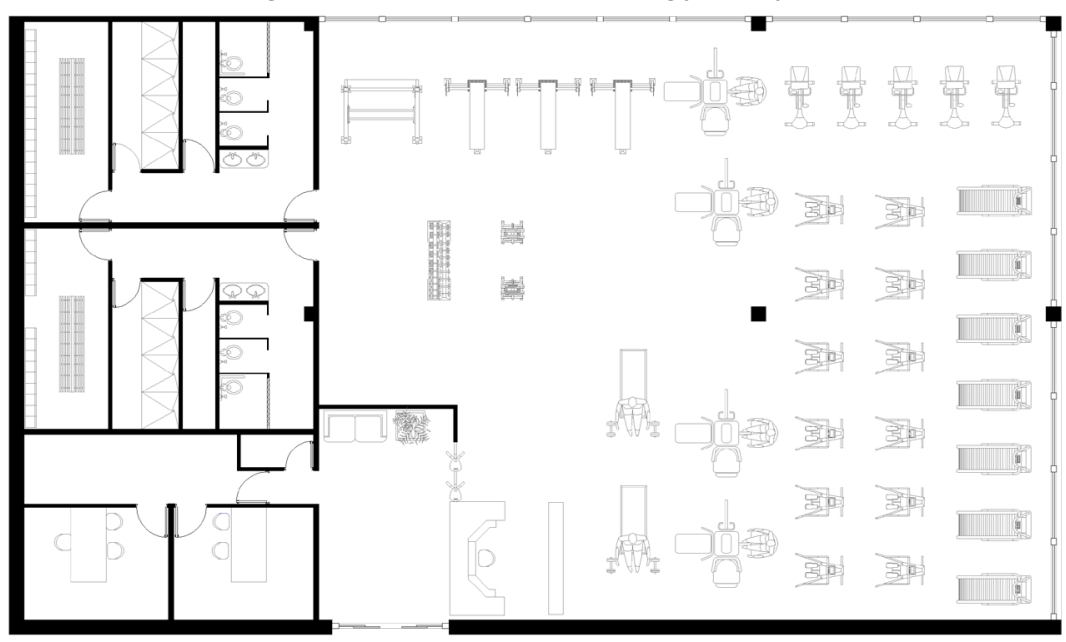

Source: The authors.

For the application of protocols in the academy model, the general guidelines, cited in Table 01, combined with the specific recommendations in Table 02 were considered.

In addition to the guidelines of the World Health Organization, this material also considers the material developed by architects [11] and experiences from countries that have already restarted the reopening of these establishments, such as Italy and China. 
Table 02: Specific recommendations for gyms

Interdiction of areas for 30 minutes for cleaning and disinfection;

Positioning of cleaning kits at strategic points in the weight training areas Containing alcohol gel, disposable towels and trash for proper disposal of material; Placement of sanitation mat at the entrance of the establishment to disinfect the shoes;

Limit the number of customers respecting the rules of social distance - minimum distance of $1.5 \mathrm{~m}$ and simultaneous occupation of 01 customers for each $4 \mathrm{~m}^{2}$

Delimitation of spaces in the areas of free weight and collective activities, where customers must exercise;

Only $50 \%$ of cardio equipment is used - exercise bikes, treadmills, elliptical trainers, walking simulators;

Keep windows and other air intake openings open for constant maintenance of ambient air.

Source: [7];[8].

In Figure 02, it can be seen how the protocols were applied by means of the symbols, to achieve the new pagination of the environment.

Figure 02: Solution model for post-pandemic academy

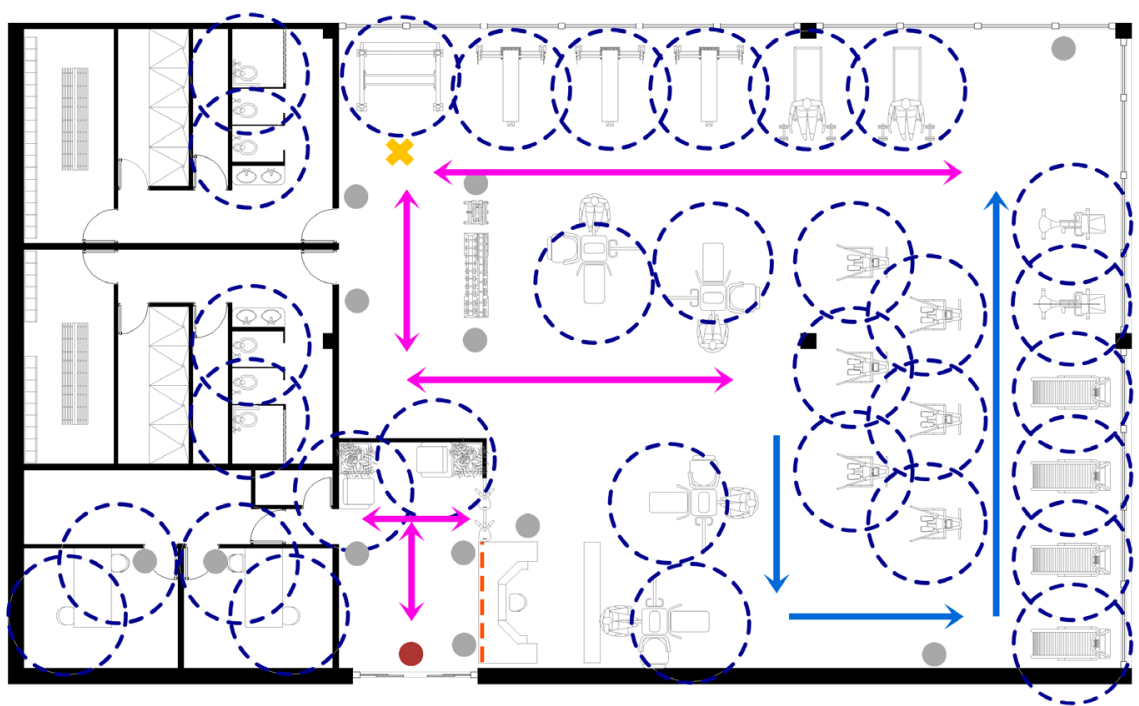

Source: The authors.

\subsection{Beauty Salon Model}


In Brazil, the beauty and aesthetics sector are among the fastest growing. Approximately 350 thousand beauty salons are formally registered in Brazil [12]. Beauty salons are considered establishments of health interest, as they pose risks to users if good practices are not employed [13]. As a result, it is essential to readjust these environments for the safe return of activities in the post-pandemic reopening.

The beauty salon model used (Figure 03) has a total area of $35.35 \mathrm{~m}^{2}$ and has 01 salon of $26.30 \mathrm{~m}^{2}, 01$ hair removal room of $05.05 \mathrm{~m}^{2}$ and a bathroom of $04.00 \mathrm{~m}^{2}$.

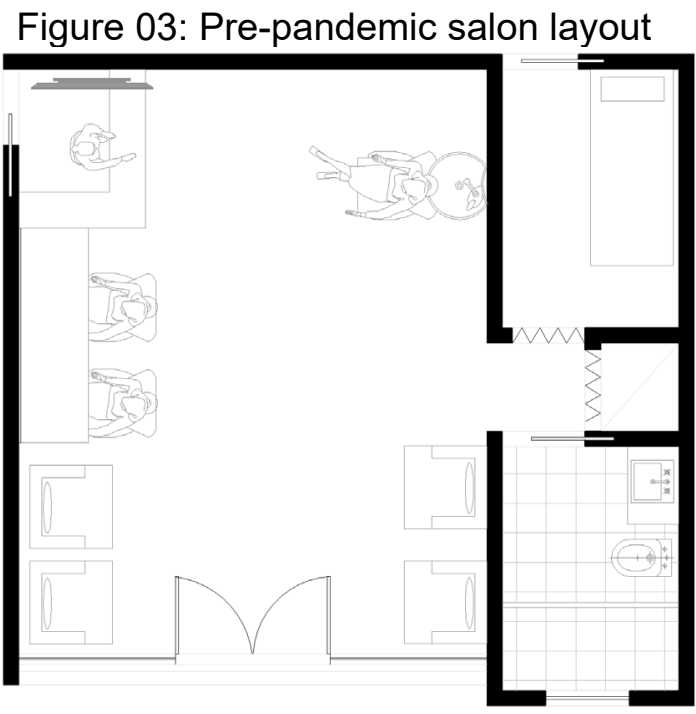

Source: The authors.

For the application of the protocols in the beauty salon model, the general guidelines, mentioned in Table 01, combined with the specific recommendations in Table 03 were considered.

Table 03: Specific recommendations for beauty salons

\begin{tabular}{l}
\hline Isolation of areas of the establishment to facilitate control of the operation; \\
\hline Provision of products for cleaning and disinfecting shoes at the entrance of \\
establishments; \\
\hline Avoid promotional activities that may cause crowds; \\
\hline $\begin{array}{l}\text { Implementation, when possible, of one-way aisles to coordinate the flow of } \\
\text { customers in stores; }\end{array}$ \\
\hline $\begin{array}{l}\text { Avoid crowding at cashiers, signal the necessary distance and use of physical } \\
\text { barriers; }\end{array}$ \\
\hline $\begin{array}{l}\text { Respected service chairs with a minimum distance of } 1.5 m \text { between them, when } \\
\text { this is not possible, use of physical barriers; }\end{array}$ \\
\hline $\begin{array}{l}\text { Entertainment materials, such as magazines and newspapers, must be removed } \\
\text { from reception to avoid shared use of these items. }\end{array}$
\end{tabular}

Source: [7];[8]. 
In Figure 04, it can be seen how the protocols were applied through the symbols (Table 01), to achieve the new pagination of the environment.

Figure 04: Solution model for post-pandemic beauty salon

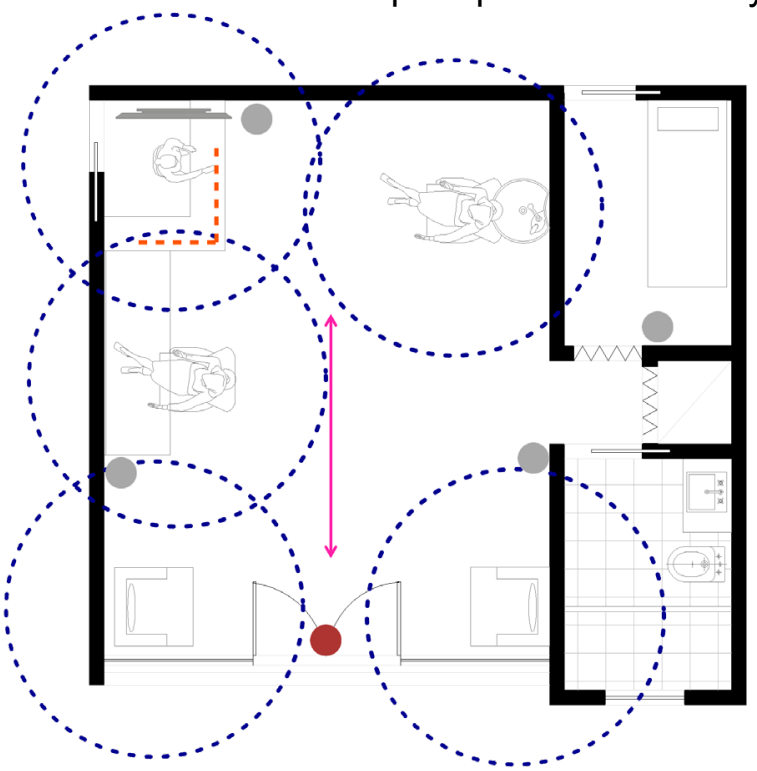

Source: The authors.

\section{RESULTS}

To facilitate the understanding of the safety guidelines in the studied environments, solutions were applied in the models that tangibly elucidate the guidelines of the health and civil construction agencies.

The starting point of the research was the choice of environments to be worked based on criteria of importance and frequent use of spaces by Brazilian society.

In the models (Figure 02) and (Figure 04), the following fundamentals were applied: marking specific areas for circulation, defining flows and queues, implementing hygiene and physical barrier points, demarcating the space to guarantee social distance and determining the maximum number of occupants.

About the occupation rates of spaces, there was a satisfactory reduction in relation to the protocols and guidelines applied. Tables 02 and 03 show the prepandemic and post-pandemic occupancy rates of the gym model and the beauty salon model, respectively.

Table 02: Pre-pandemic and post-pandemic gym occupancy rate

\begin{tabular}{l|l}
\multicolumn{1}{c|}{ Pre-pandemic situation } & \multicolumn{1}{c}{ Post-pandemic situation } \\
\hline Occupation - $100 \%-42$ people & Occupation $-52 \%-22$ people \\
\hline Cardio devices -24 people & Cardio devices -12 people \\
\hline Weight machines -18 people & Weight machines -10 people \\
\hline
\end{tabular}


Source: The authors.

Table 03: Beauty salon occupancy rate pre- and post-pandemic

\begin{tabular}{l|l}
\hline \multicolumn{1}{c|}{ Pre-pandemic situation } & \multicolumn{1}{c}{ Post-pandemic situation } \\
\hline Occupation - $100 \%-14$ people & Occupation $-57 \%-8$ people \\
\hline Waiting room area - 4 people & Waiting room area - 2 people \\
\hline Hair removal area - 2 people & Hair removal area - 2 people \\
\hline Hair area - 4 people & Hair area - 2 people \\
\hline Washed hair area- 2 people & Washed hair area- 2 people \\
\hline Cash area- 2 people & Cash area- 2 people \\
\hline
\end{tabular}

Source: The authors.

\section{CONCLUSIONS}

The solutions proposed in this work aim to provide a safe transition in the reopening of the gym and beauty salon environments, applying the guidelines and protocols of the competent bodies and facilitating the understanding of the public.

The use of digital technology tools was essential for an immediate understanding of the pre- and post-pandemic.

Based on the results presented, it is possible to affirm that the redesign of the environment contributes to the safety of the people who frequent these spaces, since they have been optimized.

Finally, it is expected that this work can contribute in a relevant way, informing and guiding the population to face this great challenge.

\section{REFERENCES}

${ }^{1}$ SANTOS, S. F.; SALLES, A. D. Antropologia de uma academia de musculação: um olhar sobre o corpo e um espaço de representação social. Revista Brasileira de Educação Física e Esporte. São Paulo-SP, p.87-102, 2009.

2 FERREIRA, D. A. Estética e sociabilidade: o salão de beleza como ponto de encontro. Revista Eletrônica de Ciências Sociais. Juiz de Fora-MG, p.275, 2017.

${ }^{3}$ ORGANIZAÇÃO MUNDIAL DE SAÚDE (OMS). Considerações sobre saúde pública e medidas sociais no local de trabalho no contexto do COVID-19. Available at: https://apps.who.int/iris/handle/10665/332050. Accessed on: 17 jul. 2020.

${ }^{4}$ Conselho de Arquitetura e Urbanismo - Distrito Federal (CAU-DF). Coronavírus: CAU/DF orienta profissionais em divulgação periódica de Protocolos. Brasília, 2020. Available at: https://www.caudf.gov.br/coronavirus-cau-df-orienta-profissionaisem-divulgacao-periodica-de-protocolo-para-obras/. Accessed on: 10 jun. 2020.

${ }^{5}$ CONSELHO DE ARQUITETURA E URBANISMO - PARAÍBA (CAU-PB) et al. Plano de gerenciamento ocupacional de combate à COVID-19 (Protocolo COVID-19). 
João Pessoa-PB, 2020. Available at: https://www.caupb.gov.br/wpcontent/uploads/2020/06/Protocolo-Covid.pdf. Accessed on: 18 jun. 2020.

${ }^{6}$ GOVERNO DO ESTADO DE SÃO PAULO (SP). Plano São Paulo - Protocolos sanitários intersetorial. São Paulo-SP, 2020. Available at: https://www.saopaulo.sp.gov.br/wp-content/uploads/2020/06/protocolo-intersetorialv-09.pdf. Accessed on: 05 jul. 2020.

7 GOVERNO DO ESTADO DE SERGIPE (SE). Retomando a economia com responsabilidade - compromisso de Sergipe. Aracaju-SE, 2020. Available at: https://www.se.gov.br/uploads/download/midia/43/a12c5498a3d5c36e1f17b1f19f71f4 40.pdf. Accessed on: 05 jul. 2020.

${ }^{8}$ FEDERAÇÃO DAS INDÚSTRIAS DO ESTADO DE SÃO PAULO (FIESP). Plano de retomada da atividade econômica após a quarentena. Available at: https://coronavirus.fiesp.com.br/blog/fiesp-lanca-protocolo-de-retomada-dasatividades-apos-quarentena. Accessed on: 10 jun. 2020.

${ }^{9}$ SABA, F. A importância da atividade física para a sociedade e o surgimento das academias de ginástica. Revista Brasileira Atividade Física \& Saúde. São Paulo-SP, p.80-87, 1998.

${ }^{10}$ INTERNATIONAL HEALTH, RACQUET \& SPORTSCLUB ASSOCIATION (IHRSA). Relatório global IHRSA - Fitness cresce no mundo e Brasil ainda sofre com a crise econômica. Revista ACAD Brasil, 2017.

11 PERKINS AND WILL. Road map for return - Guidance for a return to the office during COVID-19. Chicago-USA, 2020. Available at: https://perkinswill.com/roadmap-for-return/?utm medium=website\&utm source=archdaily.com.br. Accessed on: 10 jun. 2020.

12 SERVIÇO BRASILEIRO DE APOIO ÀS MICRO E PEQUENAS EMPRESAS (SEBRAE); ASSOCIAÇÃO BRASILEIRA DE NORMAS TÉCNICAS (ABNT). Salão de beleza - Guia de boas práticas. Rio de Janeiro-RJ, 2016. Available at: http://abnt.org.br/paginampe/biblioteca/files/upload/anexos/pdf/211055df2da423ea77 08506ab7a3be0c.pdf. Accessed on: 16 jul. 2020.

${ }^{13}$ CENTRO DE VIGILÂNCIA SANITÁRIA DO ESTADO DE SÃO PAULO. Manual de orientação para instalação e funcionamento de institutos de beleza - Sem responsabilidade médica. São Paulo-SP, 2012. Available at: http://www.cvs.saude.sp.gov.br/zip/Manual\%20est\%C3\%A9tica\%20revisado-

11set13.pdf. Accessed on: 16 jul. 2020. 